\title{
AGRO-BIODIVERSITY CONSERVATION THROUGH SEED BANKING: A CASE STUDY FROM MID-WESTERN AND FAR-WESTERN NEPAL
}

\author{
Chandra P. Pokhrel*, Vimla Bhandari, Pramesh Lakhe and Ram Kailash P. Yadav \\ Central Department of Botany \\ Tribhuvan University, Kirtipur, Kathmandu, Nepal \\ E-mail: chandraprkh@yahoo.com
}

\begin{abstract}
The present paper deals with the perception and practices of farmers on production, processing and storage of seeds as well as role of Community Seed Banks (CSBs) in seed supply and conservation of agro-biodiversity. The study was conducted in three VDCs namely Belwa, Masuriya and Beldandi of Bardia, Kailai and Kanchanpur districts, respectively. Of the sampled respondents, $44.4 \%$ used only local varieties and the rest of them used all local, improved and hybrid varieties. Farmers in the study area have their own criteria of seed selection such as yield potential, growth period, resistance to disease and pest, taste, shape and color. Traditionally, farmers store their seeds in a special clay pot called "Dehari" and "Kuthali: CSB is the alternative way of their seed storage. Total 75 varieties of paddy, 13 varieties of wheat and 10 varieties of maize were stored in CSBs. Eight varieties of millet, 5 varities of mustard and 12 varieties of pulse, 4 varieties of gram and two varieties of soybean were also stored. CSBs were found to be useful to the farmers in many ways such as easy availability of seeds, on-farm conservation of local varieties, conservation of local and traditional knowledge and change in their livelihoods.
\end{abstract}

Key words: Conservation, agrobiodiversity, community seed bank, local varieties, Nepal.

\section{INTRODUCTION}

Seed is the foundation of all agriculture. Farmers everywhere need easy access to highquality seeds of well-adapted, productive crops to allow them to produce the best possible crops. In addition, seeds are carrier of genetic diversity that contains the building blocks required for plant breeding and thus constitute the basis of all food and agricultural production in the world. Plant genetic diversity is probably more important for farming than any other environmental factors, because it enables farmers to cope with the changing environmental conditions, such as climate change. It has been found that improved and exotic varieties have replaced local crop genetic resources, thus narrowing the genetic base in agro-biodiversity and increasing the dependency of farmers to external source for their seed requirements (FAO 1996). It is estimated that $75 \%$ of crop diversity was lost between 1900 and 2000 AD (FAO 2010). With this disappearance of agrobiodiversity, global community recognized the importance of on-farm conservation of crop varieties (Regmi et al. 2007). 
The Community Seed Bank (CSB) approach is innovative; farmer led on-farm seed conservation approach, which serves both for conserving the local crop landraces as well as providing seed security to the farming communities by increasing access to genetic materials and enhancing farm level agro-biodiversity (Lewis and Mulvany 1997, Demissie and Tanto 2000). CSB also facilitates easier seed flow among farmers by increasing the availability of local seeds to farmers and by widening their varietal choices. It is emerging as an effective community institution that strengthens farmers' capacity on collection, conservation, distribution and sustainable use of local crop genetic resources for food and agriculture (Maharjan et al. 2011). In addition, CSB provides farmers with modern storage which gives the seeds longer life and better protection against pest and diseases.

The Community Seed Bank approach was introduced by the in-situ conservation project in Nepal, as an entry point to the community based management of biodiversity. It was first started in Nepal in 1995 and firstly established in Dalhowki VDC of Lalitpur district. Later on in 2003 A.D. it was established in the Kachorwa VDC of Bara District, and then established in different parts of the country. It has been piloted in various parts of country with aims to provide easy access to farmers' variety seeds at local level, knowledge documentation of traditional varieties and to promote the local seeds as well as on-farm conservation through community based conservation action (Shrestha et al. 2008). The Western Terai Landscape Complex Project (WTLCP) has also been working in 52 VDCs of the western Terai region for eight years with aims to improvement and conservation of agrobiodiversity through community participation. It fulfills the communities' requirement for quality landrace seeds and helps to increase farmers' access to quality seed as a means of conserving local crop diversity to maintain on-farm crop diversity. Therefore, the aim of the present study is to assess the perception and practices of community seed banks in western Terai region of Nepal.

\section{MATERIALS AND METHODS}

Study Area: The study was conducted in three VDCs namely Belwa, Masuriya and Beldandi, of Bardia, Kailai and Kanchanpur districts, respectively (Fig. 1). One VDC was selected from each district (Table 1). The study area lies in Western Terai Landscape Complex Project (WTLCP) and is situated in between Bardia of mid-western and Kanchanpur district of farwestern development region including Kailali district of Nepal, covering the area approximately $7200 \mathrm{~km}^{2}$. It comprises two topographically distinct zones - Terai in the south and Churiya in the north. Study sites (VDCs) were selected on the basis of diversity of landraces proposed by Regmi et al. (2007).

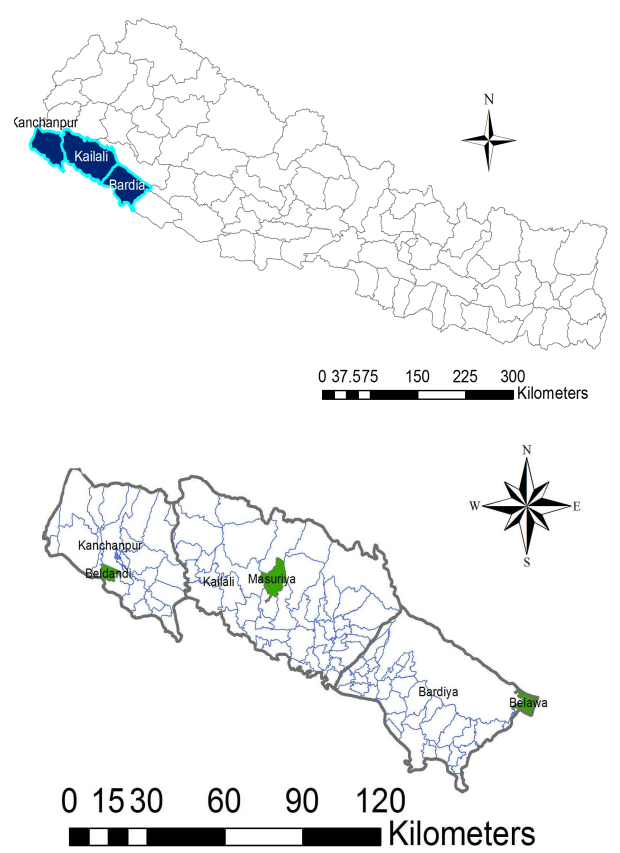

Fig. 1. Map showing districts and study area (VDCs).

ECOPRINT VOL 19, 2012 


\section{Research design and sampling}

The study was conducted during the months of November to December 2010, by using the stratified random sampling procedure. The data were collected by applying participatory approach which was stratified in terms of the socio-economic status, cast, ethnicity, gender and also in terms of different categories of cultivated (agricultural lands) fields such as khet and bari. Semi-structured questionnaire was prepared as the tool for household survey. Ninety households were taken randomly for household survey with the representation of 30 households from each research site (Table 1). Information were taken about methods used for selection, processing and storage of seeds. The perception of farmers towards the role of community seed bank were recorded. They were also asked about the benefits of agro-biodiversity conservation through local seeds. Key informant interviews were taken from project staffs, school teachers, community organization leaders, lead farmers and persons working in the seed bank. Focus group discussions were also conducted with the local people (group of 10-15 people) for consistency of the information gathered with appropriate cross checking of data. Seed banks were directly visited for the observation of management of seeds. Statistical software SPSS (version 16.0) was used to analyze the data.

Table 1. Sample size and population in each Village Development Committee (VDC).

\begin{tabular}{lccc}
\hline VDCs & Belwa & Beldandi & Masuriya \\
\hline $\begin{array}{l}\text { Level of crop } \\
\text { diversity }\end{array}$ & High & Low & Low \\
$\begin{array}{l}\text { Total number } \\
\text { of household }\end{array}$ & 2263 & 1721 & 1630 \\
\begin{tabular}{l} 
Sample size \\
\hline
\end{tabular} & 30 & 30 & 30 \\
\hline
\end{tabular}

ECOPRINT VOL 19，2012

\section{RESULTS AND DISCUSSION}

\section{Seed sources and selection process}

The study revealed that most of the seeds or planting materials of food crops were produced by local farmers. In case of need they also use to collect the required seeds from the neighboring farmers, friends or relatives and the Community Seed Bank (CSB). Occasionally they use to obtained seeds from market within or outside the village as well. Almost all respondents expressed their views in favor of locally produced seeds because of well known quality, less chance of crop failure, easy availability and low cost. Demissie and Tanto (2000) reported that CSB works as a store house of crop diversity and behaves as an emergency source of seeds if crop fail due to pests, disease or bad weather. Of the respondents, $44.4 \%$ farmers only use the local varieties of seed and $44.6 \%$ farmers use both local and improved seed while only $10 \%$ farmers used hybrid, local and improved seeds (Table 2). Farmers did not select the seeds randomly from their farm; usually they judged a variety according to their own criteria. Although yield is always important to all farmers, but small farmers tend to prefer yield stability to maximum yield. Apart from resistance to pest and diseases, other selection criteria include growth period, taste, shape, colors, secondary uses etc. After harvesting the seed of major crops such as rice, mustard, pulses and wheat are processed to remove husk and dust as well as remove inert materials by hand picking process. After drying, finally selected seeds are stored. Seeds of vegetable crops were locally collected from the healthy plants of good quality, processed and stored. Seed storage is the best way to support diversity (Lewis and Mulvany 1997). Farmers always take care of quality of seeds, cleanliness and health of the seeds. The study showed that direct involvement of farmers in the selection process led to better quality seeds. 
Table 2. Farmers' seed use pattern from different Village Development Committees (VDCs).

\begin{tabular}{lccccc}
\hline Seed variety use pattern & Belwa VDC & Masuriya VDC & Beldandi VDC & Total & Percentage (\%) \\
\hline Local & 20 & 15 & 05 & 40 & 44.4 \\
Local and improved & 10 & 11 & 20 & 41 & 45.6 \\
Local, improved and hybrid & 0 & 4 & 05 & 9 & 10 \\
Total & 30 & 30 & 30 & 90 & 100 \\
\hline
\end{tabular}

\section{Seed storage and community seed banking}

Farmers stored seeds in their own conditions. They stored their seeds in special type of clay pot which are different in size. Seeds of major crops such as paddy, wheat and mustard were stored in larger clay pots, locally known as "Dehari" which was about $5 \mathrm{ft}$ deep and $2 \mathrm{ft}$ wide. Seeds of other crops such as millet, pulses, vegetables etc. were stored in smaller clay pots, locally known as "Kuthali", which was about 2-3 ft deep and $1 \mathrm{ft}$ wide. Pots with seeds were plastered with a paste clay and cow dung and made airtight for minimum moisture content and prevented from infestation of pests, insects and diseases. Seeds of vegetables were placed in a small polythene bags and then kept them in a pot of paddy or wheat. Seeds of maize, garlic were stored by hanging the corn cob /garlic bulb in bunch either outside or inside of house. Farmers mixed or covered the seeds with the leaves of Neem (Azadiracta sp.), Titepati (Artemesia sp.), Shaypatri (Tagetus sp.) and Sishnu (Urtica dioica L.) to make the seeds disease free.

The Community Seed Bank (CSB) is another way to store seeds in the study area. CSB was managed by the members of local community. Each VDC has their own seed storage house which is operated by local community committees (Samitis). These committees were divided into subcommittees, each having 5-7 members. WTLCP provides trainings on operation and management of seed banks, participatory breeding, seed collections, storage, seed festival, viability tests of stored seeds, documentation of stored seeds, community bio-diversity documentation and other associated knowledge to agro-biodiversity conservation. Before being stored, seed samples were sent to Khajuro Seed Analysis Centre, Banke or Agriculture Research Laboratory at Sundarpur in Kanchanpur district for viability test. Only if the germination percentage is more than $80 \%$, the seeds were stored for use as propagule for the next season. Otherwise, the stored seeds were sold for food purpose on lower market price. The cereal seeds (wheat, maize, paddy) were placed in 50 and $100 \mathrm{~kg}$ plastic bags with appropriate labeling such as weight, seed variety, status, collector name, seed locality etc. Vegetable and pulse seeds were also appropriately labeled and stored in air tight plastic bottles. The study revealed that the three CSBs were found to store different varieties of landraces and thus significantly contributing to the conservation of local varieties (agro-biodiversity). Maharjan et al. (2011) reported that total number of seed varieties conserved in Belwa CSB was only 52 in 2007 and increased to 88 in 2009 and 105 in 2010. Only $55.6 \%$ of the respondents were involved in community seed bank management. Shrestha et al. (2008) reported that CSBs in western Terai of Nepal made the rare landraces available to common, ensuring seed security in local context. Adhikari (2010) reported that most of the farmers in Kailali district were illiterate and had no confidence on agro-biodiversity conservation. In contrast, this study showed that 
people who were illiterate but enthusiastic or just literate were more interested in conservation of local varieties, whereas the inert illiterate and highly educated people did not show any interest.

\section{Role of CSBs in biodiversity conservation}

During this study, CSBs were found to have given benefits to farmers in many ways such as easy availability of seeds, on-farm conservation of local varieties, conservation of local and traditional knowledge and change in livelihood (Table 3). This study also indicated that all three CSBs were contributing to sustainable conservation strategy and supporting seed exchange of traditional varieties among farmers.

In the chi-square test (Table 4), calculated chisquare value (52.62) was more than the tabulated value at $1 \mathrm{df}$ and 5\% level of significance (3.84). This implies that the household's knowledge of conservation of landraces is significantly influenced by their involvement in CSB $(p<0.001)$. Further, the expected count table indicates that the involvement of the household in CSBs increased their knowledge on the techniques to conserve landraces.

In case of the respondents' perception on the availability of seeds through seed banks, the calculated chi square value (58.22) was more than the tabulated value at $1 \mathrm{df}$ and $5 \%$ level of significance (3.84). This implies that the availability of seed to a household is significantly influenced by their involvement in CSB $(p<0.001)$. Further, the expected count table indicates that the involvement of a household in CSBs made easy availability of seeds to the households (Table 5).

Regarding respondents' perception on learning traditional techniques (Table 6), the calculated chi square value (63.00) was more than the tabulated value at $1 \mathrm{df}$ and $5 \%$ level of significance (3.84). This implies that the learning of profitable traditional knowledge and techniques by a household's is significantly influenced by its involvement in CSB $(p<0.001)$. Further, the expected count table indicates that the involvement of a household in CSBs made increased the possibility of a household $(\mathrm{HH})$ learning the profitable traditional knowledge and techniques.

As regards the change in livelihoods of local people (Table7), the calculated chi square value (37.83) was more than the tabulated value at $1 \mathrm{df}$ and 5\% level of significance (3.84). This implies that the change in livelihood of a household is significantly influenced by its involvement in CSB $(p<0.001)$. Further, the expected count table indicates that their involvement of a household in CSBs increased the possibility of change in livelihoods of a household.

Table 3. Respondent perception on different roles of community seed banks (CSBs).

\begin{tabular}{lcccccc}
\hline VDCs & $\begin{array}{c}\text { Involved } \\
\text { in CSB }\end{array}$ & $\begin{array}{c}\text { Not } \\
\text { involved in } \\
\text { CSB }\end{array}$ & $\begin{array}{c}\text { Easy } \\
\text { availability of } \\
\text { seeds }\end{array}$ & $\begin{array}{c}\text { Learn new } \\
\text { technique }\end{array}$ & $\begin{array}{c}\text { Learn } \\
\text { profitable } \\
\text { knowledge }\end{array}$ & $\begin{array}{c}\text { Change in } \\
\text { livelihoods }\end{array}$ \\
\hline Masuriya & 20 & 10 & 22 & 14 & 15 & 15 \\
Belewa & 15 & 15 & 18 & 12 & 13 & 11 \\
Beldandi & 15 & 15 & 18 & 12 & 14 & 05 \\
Total & 50 & 40 & 58 & 38 & 42 & 31 \\
Percentage & 55.6 & 44.4 & 64.4 & 42.22 & 46.7 & 34.4 \\
\hline
\end{tabular}


Table 4. Respondents' perception of CSBs role in conservation of landraces.

\begin{tabular}{|c|c|c|c|c|c|c|}
\hline & & & & \multicolumn{2}{|c|}{$\begin{array}{l}\text { Learn new techniques of } \\
\text { conservation of landraces }\end{array}$} & \multirow[t]{2}{*}{ Total } \\
\hline & & & & No & Yes & \\
\hline \multirow[t]{4}{*}{$\mathrm{HHs}$ involvement in CSB } & No & Count & & 40 & 0 & 40 \\
\hline & & Expected Count & & 23.1 & 16.9 & 40.0 \\
\hline & Yes & Count & & 12 & 38 & 50 \\
\hline & & Expected Count & & 28.9 & 21.1 & 50.0 \\
\hline \multirow{2}{*}{\multicolumn{2}{|c|}{ Total }} & Count & & 52 & 38 & 90 \\
\hline & & Expected Count & & 52.0 & 38.0 & 90.0 \\
\hline \multicolumn{7}{|l|}{ Chi-Square Test } \\
\hline & & Value & Df & \multicolumn{3}{|c|}{ Asymp. Sig. (2-sided) } \\
\hline Pearson Chi-Square & & 52.62 & 1 & \multicolumn{3}{|c|}{0.000} \\
\hline
\end{tabular}

Table 5. Respondents' perception on availability of seeds through seed banks.

\begin{tabular}{|c|c|c|c|c|c|}
\hline & & & \multicolumn{2}{|c|}{ Easily availability of seeds } & \multirow[t]{2}{*}{ Total } \\
\hline & & & No & Yes & \\
\hline \multirow[t]{4}{*}{ HHs involvement in CSB } & No & Count & 32 & 8 & 40 \\
\hline & & Expected Count & 14.7 & 25.3 & 40.0 \\
\hline & Yes & Count & 1 & 49 & 50 \\
\hline & & Expected Count & 18.3 & 31.7 & 50.0 \\
\hline \multirow[t]{2}{*}{ Total } & & Count & 33 & 57 & 90 \\
\hline & & Expected Count & 33.0 & 57.0 & 90.0 \\
\hline \multicolumn{6}{|l|}{ Chi-Square Test } \\
\hline & & Value & Df & \multicolumn{2}{|c|}{ Asymp. Sig. (2-sided) } \\
\hline Pearson Chi-Square & & 58.22 & 1 & \multicolumn{2}{|l|}{0.000} \\
\hline
\end{tabular}

Table 6. Respondents' perception for learning profitable traditional knowledge and techniques.

\begin{tabular}{|c|c|c|c|c|c|c|}
\hline & & & & \multicolumn{2}{|c|}{$\begin{array}{l}\text { Learn profitable traditional } \\
\text { knowledge and techniques }\end{array}$} & \multirow[t]{2}{*}{ Total } \\
\hline & & & & No & Yes & \\
\hline \multirow[t]{4}{*}{$\mathrm{HHs}$ involvement in CSB } & No & Count & & 40 & 0 & 40 \\
\hline & & Expected Count & & 21.3 & 18.7 & 40.0 \\
\hline & Yes & Count & & 8 & 42 & 50 \\
\hline & & Expected Count & & 26.7 & 23.3 & 50.0 \\
\hline \multirow{2}{*}{\multicolumn{2}{|c|}{ Total }} & Count & & 48 & 42 & 90 \\
\hline & & Expected Count & & 48.0 & 42.0 & 90.0 \\
\hline \multicolumn{7}{|l|}{ Chi-Square Test } \\
\hline & & Value & Df & \multicolumn{3}{|c|}{ Asymp. Sig. (2-sided) } \\
\hline Pearson Chi-Square & & 63.00 & 1 & \multicolumn{3}{|c|}{0.000} \\
\hline
\end{tabular}


Table 7. Respondents' perception on change in their livelihoods.

\begin{tabular}{lllccc}
\hline & & \multicolumn{2}{c}{ Change in livelihood } & Total \\
& & & No & Yes & \\
\hline HHs involvement in CSB & No & Count & 40 & 0 & 40 \\
& & Expected Count & 26.2 & 13.8 & 40.0 \\
& Yes & Count & 19 & 31 & 50 \\
Total & & Expected Count & 32.8 & 17.2 & 50.0 \\
& & Count & 59 & 31 & 90 \\
Chi-Square Test & Expected Count & 59.0 & 31.0 & 90.0 \\
& & & & \multicolumn{2}{c}{ Asymp. Sig. (2-sided) } \\
Pearson Chi-Square & Value & Df & \multicolumn{2}{c}{0.000} \\
\hline
\end{tabular}

Table 8. Paddy, Wheat and Maize varieties stored in Seed banks.

\begin{tabular}{|c|c|c|c|c|}
\hline \multicolumn{2}{|l|}{ VDC } & \multirow[b]{2}{*}{$\begin{array}{l}\text { Rice } \\
\text { Lalchand, Jhinua, Mansara, Southiyari, Nimoi, } \\
\text { Kalonathy, Lalchan, Ghiyupuri, Ratanpuri, Bagari, } \\
\text { Thapachini, Anjana, Setosatha, Kalosatha, } \\
\text { Bhattykholy, Junali, Gopala, Tilki, Suhawat, } \\
\text { Bindiya, Shyamjira, Tarkan, Ghunmuniya, } \\
\text { Belkholey, Dirua, Karangi }\end{array}$} & \multirow{2}{*}{$\begin{array}{l}\text { Wheat } \\
\text { Seto gahun, } \\
\text { Bhrikuti }\end{array}$} & \multirow[b]{2}{*}{$\begin{array}{l}\text { Maize } \\
\text { Murali makai, } \\
\text { Rana makai, } \\
\text { Tharu makai, } \\
\text { Chaudhari } \\
\text { makai, Local } \\
\text { makai Rato } \\
\text { makai, Seto } \\
\text { makai }\end{array}$} \\
\hline Belewa & Local & & & \\
\hline & Improved & $\begin{array}{l}\text { Radha-4, Hardinath, Ramdhan, Natiza, Mithila } \\
\text { judi-582, Barkhey-1024 }\end{array}$ & $\begin{array}{l}\text { Gautam, Kundan, } \\
\text { BL-2800, NL- } \\
\text { 297, BL-3264, } \\
\text { UG-1053, UG- } \\
\text { 1073, NL-1053 }\end{array}$ & $\begin{array}{l}\text { Baisakhi, Arun } \\
\text { II, Rampur }\end{array}$ \\
\hline \multirow[t]{2}{*}{ Masuriya } & Local & $\begin{array}{l}\text { Anadi, Anjana, Bagari, Belkhola, } \\
\text { Bhatteykhola,Ghiyupuri,Jhinua,Kalobasmati, } \\
\text { Kalonath, Karangi, Lalchand, Marsi, Nirmohi, } \\
\text { Pushabasmati, Rahimanua,Ratanpuri, Shyamjira, } \\
\text { Suhawat, Talkand, Thapachini, Tilakchand, Tilaki, } \\
\text { Mansara, Soundhyari }\end{array}$ & $\begin{array}{l}\text { Rato gahun, Seto } \\
\text { gahun, Bhrikuti }\end{array}$ & $\begin{array}{l}\text { Rato makai, } \\
\text { Seto makai, } \\
\text { Murali makai }\end{array}$ \\
\hline & Improved & $\begin{array}{l}\text { Radha-4, Sabitri, Hardinath-1, Ramdhan, Ghaiya, } \\
\text { Barkhy-214, Judi-582, Natiza }\end{array}$ & $\begin{array}{l}\text { Gautam, Kundan, } \\
\text { BL-2800, NL- } \\
297, \text { BL-3264, } \\
\text { BL-3063, UG- } \\
\text { 1053, UG-1073, } \\
\text { NL-1053 }\end{array}$ & $\begin{array}{l}\text { Arun II, } \\
\text { Rampur }\end{array}$ \\
\hline \multirow[t]{2}{*}{ Beldandy } & Local & $\begin{array}{l}\text { Suhawat, Talkanj, Jarua, Basnadar- anadi, Suga } \\
\text { pankhi, KaloJadhan, Shayam Jira, Kalobsmati, } \\
\text { Rahemanua, Junmuniya, Jhinwa, Tilki, Jadhaniya- } \\
\text { Anadi, Mansara, Kalonath, Ghiyupuri, Karangi, } \\
\text { Kalo satha, Thapachini, Belkheyle, LalChand, } \\
\text { Ratanpuri, Bagari, Anjana, Nimoi, Larangi, } \\
\text { Manjira, Madhukar, Lwang, Manhara }\end{array}$ & $\begin{array}{l}\text { Bangohunwa, } \\
\text { Rato gahun, Seto } \\
\text { gahun, Bhrikuti }\end{array}$ & $\begin{array}{l}\text { Chaudhari } \\
\text { makai, } \\
\text { Localmakai } \\
\text { Rato makai }\end{array}$ \\
\hline & Improved & $\begin{array}{l}\text { Radha-4, Radha-12, Hardinath-1, Judi-582, } \\
\text { Mithila, Sunowlo-sugandha, Barkhey-1024, } \\
\text { Barkhey-1036, Barkhey-2014, Barkhey-3019 PVS, } \\
\text { Barkhey-3004, Barkhey-3017-7, Barkhey-3017-5, } \\
\text { Madhayam-846, Madhayam-741, Madhayam-742, } \\
\text { Madhayam-743, Madhayam-744, Madhayam-906, } \\
\text { Madhayam-845, Madhayam-904, Sawitri-barkhey - } \\
\text { PH290, Sawitri -barkhey -1027 PH52, Khajura } \\
125\end{array}$ & $\begin{array}{l}\text { Gautam, Kundan, } \\
\text { BL-2800, BL- } \\
3264, \text { BL-3063, } \\
\text { UG-1053, NL- } \\
1053\end{array}$ & $\begin{array}{l}\text { Arun II, } \\
\text { Rampur, } \\
\text { Baisakhi }\end{array}$ \\
\hline
\end{tabular}


Table 9. Local and improved varieties other than cereals stored in seed banks.

\begin{tabular}{ll}
\hline & Local and improved varieties \\
\hline Millet (Eleusine coracana) & Jhaure kodo, Kalo kodo, Thulo kodo, Muduare kodo, Seto kodo, Rato kodo, \\
& Tin masy kodo, Kopi kodo \\
Mustard (Brassica sp) & Kalo local tori, Pahelo local, Gobhi tori, Sarsig, Lahata-6 varities \\
Gram & Avarodhi, Sita, Tara, Sano chana-local, \\
Pulses Varieties & $\begin{array}{l}\text { Hinuady mass-local, Varkhymass-local, Pratikhsha mung, Kalyani mung, } \\
\text { Sano local mung, Laharay mass, Botey mass, Simal masuro(lentil), Sagun } \\
\text { masuro, Khajura masuro, Kalo masuro local, Khairo masuro local }\end{array}$ \\
Soya bean (Glycine max) & Kalo Bhatmass, Seto Bhatmass \\
\hline
\end{tabular}

\section{Documentation of the major cultivars}

Paddy (Oryza sativa), wheat (Triticum aestivum) and maize (Zea mays) are cultivated as major crops including millet, soybean and various pulses. A total of 75 varieties of paddy were found stored in CSBs; out of that 45 were local varieties. Similarly 13 varieties of wheat and 10 varieties of maize were stored in CSBs; among them only 4 were the local varieties of wheat and 7 were the local varieties of maize. Eight varieties of millet, 5 verities of mustard, 12 varieties of pulse, 4 varieties of gram and two varieties of soybean were also stored in the CSBs. The cereals and other varieties stored in CSBs are presented in Tables 8 and Table 9.

\section{Conclusion}

The Community Seed Banking (CSB) is innovative to farmers and is based on on-farm seed conservation approach. This serves both, conserving the local landraces as well as providing seed security to the farming communities by increasing access to genetic materials and enhancing farm level agro-biodiversity. This study also indicated that community seed banks (CSBs) at VDC level are effectively contributing to sustainable conservation strategy and supporting seed exchange of traditional varieties among farmers.

\section{Acknowledgements}

The Western Terai Landscape Complex Project (WTLCP), GoN provided financial support to carry out the study. The authors also acknowledge the local people and members of the community seed banks of the study area for their valuable support during field study.

\section{REFERENCES}

Adhikari, A. 2010. Agro-biodiversity conservation practices in Kailali district, Nepal. M.Sc. Thesis. College of Applied Science, Kathmandu, Nepal.

Demissie, A. and T. Tanto. 2000. Dynamic Participatory Approach to the Use of Plant Genetic Resources. Institute of Biodiversity Conservation and Research. Addis Ababa.

FAO. 1996. Report on the status of the world's plant genetic resources for food and Agriculture. Prepared for the International Technical Conference on Plant Genetic Resources, Leipzing, Germany 17-23 June. Food and Agriculture Organization of United Nations, Rome.

FAO. 2010. The Second Report on the State of the World's Plant Genetic Resources. Food and Agriculture Organization, United Nations, Rome.

ECOPRINT VOL 19, 2012 
Lewis, V. and P. Mulvany. 1997. A Typology of Community Seed Bank. Natural Resource Institute, University of Greenwitch, Kent.

Maharjan, S.K., A.R. Gurung and B.R. Sthapit. 2011. Enhancing on-farm conservation of agrobiodiversity through community seed Banking: An experience of western Nepal. The Journal of Agriculture and Environment 12:132-133.

Regmi, B.R., P. Shrestha, A. Adhikari, A.R. Khanal, I. Poudyal, H. Poudyal and B.P. Mahato. 2007. Western Terai Landscape
Project Agrobiodiversity Component, Site Selection Report. LI-BIRD, Pokhara, Nepal.

Shrestha, P.B., B. Sthapit, A. Subedi, D. Poudyal, P. Shrestha, M. Upadhayay and B. Joshi. 2008. Community Seed Bank: Good practice for on-farm conservation of agricultural biodiversity. In: On Farm Management of Agriculture Biodiversity in Nepal. (eds.) Sthapit, B.R., D. Gauchan, A. Subedi and D. Jarvish. Biodiversity International. NARC/LIBIRD/IDRC/SDC. pp. 112-114. 